\title{
Agronomic Evaluation of Sweet Sorghum in Semiarid Region: Cultivar and Spacing Effects
}

\author{
Tatiana Maria da Silva ${ }^{1}$, Alexandre Bosco de Oliveira ${ }^{1}$, Joana Gomes de Moura ${ }^{2}$, Bruno França da Trindade Lessa ${ }^{3}$ \\ \& Lamartine Soares Cardoso de Oliveira ${ }^{1}$ \\ ${ }^{1}$ Federal University of Ceará, Fortaleza, Ceará, Brazil \\ ${ }^{2}$ Federal University of Paraíba, Paraíba, Areia, Brazil \\ ${ }^{3}$ Federal University of São Francisco Valley, Petrolina, Pernambuco, Brazil \\ Correspondence: Alexandre Bosco de Oliveira, Federal University of Ceará, Av. Mister Hull, 2977, Fortaleza, \\ Ceará, Brazil. Tel: 55-85-3366-9419. E-mail: aleufc@gmail.com
}

Received: June 11, 2018

doi:10.5539/jas.v10n10p103
Accepted: July 10, $2018 \quad$ Online Published: September 15, 2018

URL: https://doi.org/10.5539/jas.v10n10p103

\begin{abstract}
The objective of this study was to evaluate the agronomic characteristics of two sweet sorghum varieties for row spacing in the semiarid region of the State of Ceará, Brazil. Hence, an experiment was carried out on the Experimental Farm of the Federal University of Ceará, in two agricultural cycles (2015 and 2016), in sandy loam Planosol during the rainy season. Two sweet sorghum varieties (BRS 506 and SF 15), cultivated at 50, 60, 70, and $80 \mathrm{~cm}$ row spacing, were evaluated at different times after sowing $(30,45,60,75$, and 90 days), in a randomized block design repeated four times in the arrangement of subdivided plots $(2 \times 4 \times 5)$. The BRS 506 variety had higher mean number of leaves and leaf angle +3 in the two cycles evaluated. The highest mean plant height was observed at 90 DAS $(328.11 \mathrm{~cm})$. The stalk diameter at $15.59 \mathrm{~mm}$ was greatest with $70 \mathrm{~cm}$ spacing between rows. The chlorophyll content of the leaves may be influenced by stress factors, such as water and mineral deficiency, primarily nitrogen. The best results for chlorophyll occurred in the first cycle, in which the greatest mean was observed at 75 days, while in the second cycle, a year that presented low precipitation (water stress), the greatest means were observed at 30 days. Taking into consideration our results, BRS 506 variety is recommended for cultivation in semiarid northeastern Brazil, presenting good agronomic characteristics, when sown with $70 \mathrm{~cm}$ spacing between the rows.
\end{abstract}

Keywords: Sorghum bicolor (L.) Moench, semiarid, agronomic evaluations, vegetable pigments, ethanol

\section{Introduction}

The semiarid region of Brazil has climatic characteristics that often limit agricultural production under natural conditions, due to its intense insolation, high temperatures, and irregular rainfall generally concentrated in a short period of time. This scenario has been intensifying by climate change (Moura et al., 2007; Oliveira et al., 2012; Nunes et al., 2014). Sweet sorghum (Sorghum bicolor (L.) Moench) is a promising crop for these regions, due to its hardiness and resistance to abiotic stresses (Oliveira et al., 2011, 2017a).

Sweet sorghum can be harvested between the period of sugarcane harvests, thus benefiting the sugarcane industry, by reducing the idle time and generating raw material to produce ethanol during this period. It produces substantial biomass, has an early harvest, and uses the same industrialization process as sugarcane. These factors make it the first option for the renewal of the cultivation area, aiming to anticipate the milling period by about 45 days (Santos et al., 2015; Silva et al., 2018).

Crop production might be increased without increasing the cultivated area mainly due to the use of cultivars with greater productive potential as well as the appropriate cultivation management. The arrangement of plants can be accomplished by altering the number of plants in the row and the spacing between the planting rows, to increase the yield and to improve the distribution of the plants in the area. This can increase the efficient use of water, solar radiation, and the nutrients available, as well as control weeds. These studies provide information on how to reduce intraspecific competition and maximize the use of environmental resources (Bellaloui et al., 2015; Souza et al., 2016; Costa et al., 2017; Silva et al., 2017a). 
Fernandes et al. (2014) show that the reduction of row spacing, in the sweet sorghum crop, provides agronomic gains, which are important for ethanol production. Among the most influential factors, Fischer-Filho et al. (2014) emphasized the production of stalk (height and diameter), which provides greater or less broth production as a function of the green biomass. Consequently, the sowing arrangements should provide the greatest increase of these variables at harvest time.

In addition, crop spacing can change the light exposure and provide adjustments of the photosynthetic apparatus of the plants, which results in greater efficiency in the absorption and transfer of energy to the photosynthetic processes. The contents of chloroplastidic, chlorophyll, and carotenoid pigments can be used as important markers of plant environment (Martins et al., 2010).

Mekad and Rady (2016) studied the behavior of five varieties of sweet sorghum and three planting densities $\left(111,000 ; 133,000\right.$; and 166,000 plants/ $\left.\mathrm{ha}^{-1}\right)$ in dry environments in Egypt and found that potential crop productivity can be better exploited when agronomic practices, such as density, are used. They showed that stalk diameter, stalk weight, and leaf weight significantly increase when grown at higher density.

To take full advantage of the real conditions faced in the northeastern Brazil, our objective was to evaluate the agronomic characteristics of two sweet sorghum varieties as a function of the spacing between rows in the semiarid region of the state of Ceará.

\section{Method}

\subsection{Location and Climatic Conditions}

The experiment was installed at the Curu Valley Experimental Farm belonging to the Universidade Federal do Ceará, Pentecoste, CE (coordinates UTM 462620 E, $9577349 \mathrm{~S}$ and altitude of $48 \mathrm{~m}$ ) in sandy loam Planosol (Embrapa, 2013). Two agricultural cycles were carried out. The first crop cycle occurred between March and July 2015, a period that includes the rainy season in the region, with manual sowing performed on March 7 . The experiment was repeated in 2016, with sowing on March 18 and extending until the month of June.

The region has BSw'h' climate, i.e. a semiarid climate with irregular rains (Alvares et al., 2014). The meteorological data for the experiment are shown in Figure 1.
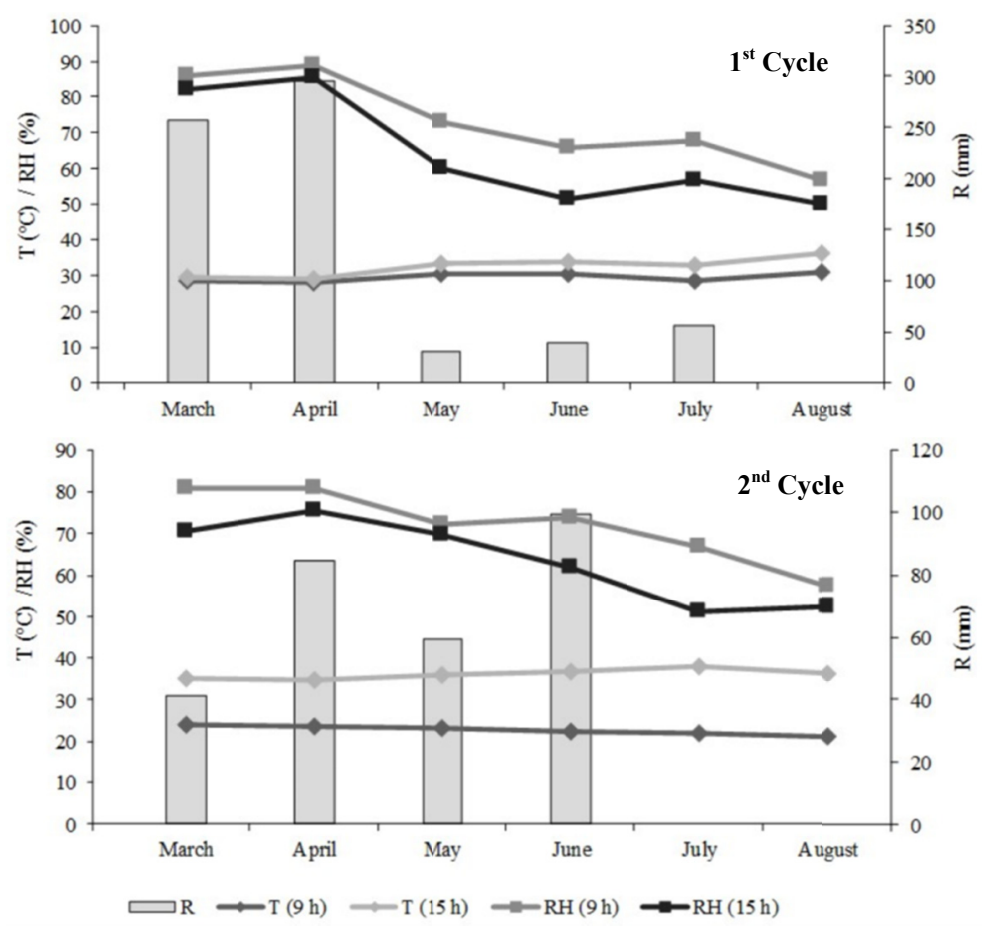

Figure 1. Main meteorological parameters for the period from March to August in each cultivation year of the experiment (2015 and 2016) in Pentecoste, CE, Brazil

Source: FUNCEME (www.funceme.br). T: Temperature. RH: Relative Humidity. R: accumulated monthly rainfall. $\mathrm{T}(9 \mathrm{~h})=\mathrm{T}(09: 00) ; \mathrm{T}(15)=\mathrm{T}(15: 00)$; RH $(9 \mathrm{~h})=\mathrm{RH}(09: 00) ; \mathrm{RH}(15 \mathrm{~h})=\mathrm{RH}(15: 00)$. 


\subsection{Plant Materials and Preparation of the Experimental Area}

The varieties used were BRS 506, acquired from the Brazilian Agricultural Research Corporation (EMBRAPA), Corn and Sorghum located in Sete Lagoas, MG, and SF-15, provided by the Instituto Agronômico de Pernambuco (IPA) located in Recife, PE.

Soil preparation was performed with plowing followed by harrowing. According to the soil analysis (Appendix A: Tables A1 and A2) of the experiment area and recommendations of Silva et al. (2017b), the crop was fertilized with 30,50 , and $45 \mathrm{~kg} \mathrm{ha}^{-1}$ of $\mathrm{N}, \mathrm{P}_{2} \mathrm{O}_{5}$, and $\mathrm{K}_{2} \mathrm{O}$, respectively, at the time of sowing for both years, taking as sources for each nutrient the mineral fertilizers urea, simple superphosphate, and potassium chloride. Twenty days after sowing, a topdressing was applied of fertilizer with 140 and $45 \mathrm{~kg} \mathrm{ha}^{-1}$ of $\mathrm{N}$ and $\mathrm{K}_{2} \mathrm{O}$, respectively.

\subsection{Experimental Design and Conduction}

For the two varieties studied (BRS 506 and SF-15), the rows spacing of 50,60, 70, and $80 \mathrm{~cm}$ (with the spacing between plants standardized at $12 \mathrm{~cm}$ ) were analyzed at 30, 45, 60, 75, and 90 days after sowing. The randomized block design repeated four times in the arrangement of split-plots $(2 \times 4 \times 5)$, for a total area of $1,248 \mathrm{~m}^{2}$, with four blocks of $312 \mathrm{~m}^{2}$ and plots ranging from 10 to $16 \mathrm{~m}^{2}$ according to the treatment. Each plot consisted of four rows of five meters, the two central rows being the useful area of the plot.

\subsection{Data Collection and Analyzed Variables}

Six plants were evaluated for each experimental unit, with measurements taken every 15 days. The morphological parameters analyzed were plant height (PH); stalk diameter (SD); number of leaves (NL); leaf angle +3 (LA); chlorophyll a, b, total; and chlorophyll a/b ratio.

To determine the height of the plant, the measurement was taken from the soil surface to the base of the flag leaf (vegetative stage) or panicle apex (reproductive stage). For the stalk diameter, a digital caliper was used to determine the diameter from the average of three readings taken at the base, middle, and apex of each plant. The leaf angle +3 (LA), the angle of the third leaf-blade junction relative to the main stalk from the apex down, was determined by measuring its curvature using a protractor to determine the angle formed by the leaf. The number of leaves (NL) was determined by counting the fully expanded leaves. The relative chlorophyll index was performed through the ClorofiLOG meter-CFL1030, and readings were done on three parts of the leaf +3 , base, middle, and apex, with subsequent averaging.

\subsection{Statistical Analyzes}

The data were submitted to tests of normality and homogeneity of the variances, and when such assumptions were met, analysis of variance (ANAVA) with Tukey test (5\%) were made for the varieties and polynomial regression for the spacing between the rows and for the different times after the sowing. The data that did not meet at least one of the assumptions were submitted to Kruskal-Wallis non-parametric test, with multiple comparisons in pairs with p-value $\leq 0.05$ and level of significance at $5 \%$.

The chlorophyll $\mathrm{a}^{2}$ and total chlorophyll ${ }^{2}$ variables were submitted to data transformation through the Boxcox system, which made it possible to adjust the data for the ANOVA.

Statistical analyzes were performed with the software Action 2.7 (ESTATCAMP, 2016) for Boxcox transformation, Bartlett test (test of variance), and Kruskal-Wallis test; Assistat 7.7 beta (Silva \& Azevedo, 2009) for the tests of normality; and Sisvar 5.3 Build 77 (Ferreira, 2011) for ANOVA with Tukey or regression.

\section{Results}

The average values for plant height in the two years of cultivation were not significantly difference $(p>0.05)$ for the varieties and the spacing between the rows studied. Nevertheless, from the first to the second crop cycle, plants height decreased $59 \mathrm{~cm}$, in the $50 \mathrm{~cm}$ spacing, and decrease $53.5 \mathrm{~cm}$ in the $80 \mathrm{~cm}$ spacing. During the evaluation period, the plant height increased $247.66 \mathrm{~cm}$ in the first cycle and $153.43 \mathrm{~cm}$ in the second crop cycle, from 30 to 90 days after sowing (DAS) (Table 1).

The BRS 506 variety presented a significant difference $(p>0.05)$ in the highest mean number of leaves and leaf angle +3 , observed in the two crop cycles, with an increase of $10.76^{\circ}$ in the leaf angle +3 from the first to the second cycle. While the spacing between the rows did not show any significant difference. The highest mean number of leaves was observed at 60 DAS, while the greatest angle occurred at 90 DAS for both crop cycles (Table 1). 
Table 1. Plant height $\left(\mathrm{PH}^{1 \varepsilon_{2}}\right)$, number of leaves $\left(\mathrm{NL}^{1 \&_{2}}\right)$, and leaf angle $\left(\mathrm{ANG}^{1{ }^{k_{2}}}\right)$ of two sweet sorghum varieties submitted to different spacing between the rows

\begin{tabular}{|c|c|c|c|c|c|c|}
\hline Treatments & $\mathrm{PH}^{1}$ & $\mathrm{PH}^{2}$ & $\mathrm{NL}^{1}$ & $\mathrm{NL}^{2}$ & $\mathrm{ANG}^{1}$ & $\mathrm{ANG}^{2}$ \\
\hline & \multicolumn{4}{|c|}{ |------------------------------------- cm ------------------------------------- } & \multicolumn{2}{|c|}{  } \\
\hline \multicolumn{7}{|l|}{ Varieties } \\
\hline BRS 506 & $225.01 \mathrm{a}$ & $179.32 \mathrm{a}$ & $7.54 \mathrm{a}$ & $6.43 \mathrm{a}$ & $41.39 \mathrm{a}$ & $52.15 \mathrm{a}$ \\
\hline SF-15 & $230.48 \mathrm{a}$ & $176.90 \mathrm{a}$ & $7.08 \mathrm{~b}$ & $5.90 \mathrm{~b}$ & $33.72 \mathrm{~b}$ & $36.01 \mathrm{~b}$ \\
\hline \multicolumn{7}{|c|}{ Row Spacing $(\mathrm{cm})$} \\
\hline 50 & $232.41 \mathrm{a}$ & $173.41 \mathrm{a}$ & $7.20 \mathrm{a}$ & $5.99 \mathrm{a}$ & $36.67 \mathrm{a}$ & $42.60 \mathrm{a}$ \\
\hline 60 & $223.55 \mathrm{a}$ & $182.10 \mathrm{a}$ & $7.01 \mathrm{a}$ & $6.25 \mathrm{a}$ & $35.60 \mathrm{a}$ & $43.14 \mathrm{a}$ \\
\hline 70 & $226.35 \mathrm{a}$ & $181.80 \mathrm{a}$ & $7.44 \mathrm{a}$ & $6.52 \mathrm{a}$ & $38.20 \mathrm{a}$ & $46.15 \mathrm{a}$ \\
\hline 80 & $228.65 \mathrm{a}$ & $175.14 \mathrm{a}$ & $7.60 \mathrm{a}$ & $6.14 \mathrm{a}$ & $39.76 \mathrm{a}$ & $44.43 \mathrm{a}$ \\
\hline \multicolumn{7}{|l|}{ Time $(D A S)$} \\
\hline 30 & $80.45 \mathrm{c}$ & $81.18 \mathrm{~d}$ & $6.28 \mathrm{c}$ & $5.92 \mathrm{~b}$ & $27.50 \mathrm{c}$ & $31.87 \mathrm{~d}$ \\
\hline 45 & $170.11 b c$ & $149.53 \mathrm{c}$ & $8.17 \mathrm{a}$ & $4.67 \mathrm{c}$ & $24.56 \mathrm{c}$ & $39.56 \mathrm{c}$ \\
\hline 60 & $256.09 \mathrm{~b}$ & $204.40 \mathrm{~b}$ & $8.73 \mathrm{a}$ & $8.08 \mathrm{a}$ & $34.67 \mathrm{~b}$ & $45.57 \mathrm{~b}$ \\
\hline 75 & $313.94 \mathrm{a}$ & $220.83 \mathrm{a}$ & $7.19 \mathrm{~b}$ & $5.86 \mathrm{~b}$ & $40.41 \mathrm{~b}$ & $51.12 \mathrm{a}$ \\
\hline 90 & $328.11 \mathrm{a}$ & $234.61 \mathrm{a}$ & $6.19 \mathrm{c}$ & $6.28 \mathrm{~b}$ & $60.64 \mathrm{a}$ & $52.28 \mathrm{a}$ \\
\hline
\end{tabular}

Note. ${ }^{1}$ : first cycle; ${ }^{2}$ : second cycle; RS: spacing between row; DAS: days after sowing.

Means followed by equal letters in the columns do not differ from each other by the non-parametric Kruskal-Wallis test $(\mathrm{K}-\mathrm{W})$, with multiple comparisons in pairs with p-value $\leq 0.05$; level of significance at $5 \%$.

The relative indexes of chlorophyll for the first cycle, in Table 2, for the BRS 506 variety showed significant difference ( $p>0.05$ ) for chlorophyll a, $b$, and total, with means of 33.98, 9.24, and 43.21, respectively. The SF15 variety only presented a higher mean for the chlorophyll $\mathrm{a} / \mathrm{b}$ ratio at 4.22 . No significant differences were observed for the spacing between rows evaluated.

At 60 and 75 days after sowing, the highest mean of chlorophyll a was observed, while the chlorophyll $b$ and total were higher from 60 to 90 DAS. The chlorophyll a/b ratio was higher at 30 and 45 DAS, with means of 4.36 and 4.59 , respectively.

Table 2. Relative index of chlorophyll, chlorophyll a (Chlor $\left.\mathrm{a}^{1}\right)$, chlorophyll b (Chlor $\left.\mathrm{b}^{1}\right)$, total chlorophyll (Chlor tota $\left.{ }^{1}\right)$, and chlorophyll $a / b$ ratio $\left(a / b^{1}\right.$ ratio) of two sweet sorghum varieties submitted to different spacing between the rows

\begin{tabular}{|c|c|c|c|c|}
\hline Treatments & Chlor a $^{1}$ & ${\text { Chlor } b^{1}}^{1}$ & Chlor total $^{1}$ & $\mathrm{a} / \mathrm{b}^{1}$ Ratio \\
\hline \multicolumn{5}{|l|}{ Varieties } \\
\hline BRS 506 & $33.98 \mathrm{a}$ & $9.24 \mathrm{a}$ & $43.21 \mathrm{a}$ & $3.79 \mathrm{~b}$ \\
\hline SF-15 & $32.11 \mathrm{~b}$ & $7.77 \mathrm{~b}$ & $39.88 \mathrm{~b}$ & $4.22 \mathrm{a}$ \\
\hline \multicolumn{5}{|l|}{$R S(\mathrm{~cm})$} \\
\hline 50 & $33.15 \mathrm{a}$ & $8.72 \mathrm{a}$ & $41.86 \mathrm{a}$ & $3.91 \mathrm{a}$ \\
\hline 60 & $32.85 \mathrm{a}$ & $8.10 \mathrm{a}$ & $40.95 \mathrm{a}$ & $4.12 \mathrm{a}$ \\
\hline 70 & $32.76 \mathrm{a}$ & $7.99 \mathrm{a}$ & $40.75 \mathrm{a}$ & $419 a$ \\
\hline 80 & $33.41 \mathrm{a}$ & $9.21 \mathrm{a}$ & $42.61 \mathrm{a}$ & $3.80 \mathrm{a}$ \\
\hline \multicolumn{5}{|l|}{ Time (DAS) } \\
\hline 30 & $32.18 \mathrm{~b}$ & $7.40 \mathrm{~b}$ & $39.59 \mathrm{~b}$ & $4.36 \mathrm{a}$ \\
\hline 45 & $32.84 \mathrm{ab}$ & $7.21 \mathrm{~b}$ & $40.05 \mathrm{ab}$ & $4.59 \mathrm{a}$ \\
\hline 60 & $33.96 \mathrm{a}$ & $8.88 \mathrm{a}$ & $42.84 \mathrm{a}$ & $3.88 \mathrm{~b}$ \\
\hline 75 & $34.46 \mathrm{a}$ & $9.58 \mathrm{a}$ & $44.04 \mathrm{a}$ & $3.69 \mathrm{~b}$ \\
\hline 90 & $31.76 \mathrm{~b}$ & $9.45 \mathrm{a}$ & $41.20 \mathrm{a}$ & $3.50 \mathrm{~b}$ \\
\hline
\end{tabular}

Note. ${ }^{1}$ : first cycle; ${ }^{2}$ : second cycle; RS: spacing between row; DAS: days after sowing.

Means followed by equal letters in the columns do not differ from each other by the non-parametric Kruskal-Wallis test $(\mathrm{K}-\mathrm{W})$, with multiple comparisons in pairs with $\mathrm{p}$-value $\leq 0.05$; level of significance at $5 \%$. 
There was a significant difference for the factors of variety ( $p>0.01)$, row spacing $(p>0.05)$, and time $(p>0.01)$ for stalk diameter in the second cycle. Total chlorophyll in the second cycle was significantly difference $(\mathrm{p}>$ 0.01 ) only for the time variation factor (Table 3).

A significant difference $(p>0.01)$ was observed for the interaction between variety and time (DAS) for the variables stalk diameter (first cycle) and chlorophyll $b$ and chlorophyll $a / b$ ratio (second cycle), but the low values of the coefficient of variation are worth noting (Table 3 ).

Table 3. ANOVA summary of the variables: mean stalk diameter (Diam $\left.{ }^{1 \varepsilon_{2}}\right)$, chlorophyll a $\left(\right.$ Chlor a $\left.a^{2}\right)$, chlorophyll $\mathrm{b}\left(\mathrm{Chlor}^{2}\right)$, total chlorophyll $\left(\right.$ Chlor total $\left.{ }^{2}\right)$, and chlorophyll $\mathrm{a} / \mathrm{b}$ ratio $\left(\mathrm{a} / \mathrm{b}^{1}\right.$ ratio) of two sweet sorghum varieties due to different row spacing

\begin{tabular}{|c|c|c|c|c|c|c|c|}
\hline VF & DF & $\operatorname{Diam}^{1}$ & $\operatorname{Diam}^{2}$ & Chlor ta ${ }^{2}$ & Chlor $\mathrm{tb}^{2}$ & Total Chlor $^{2}$ & Ratio $a / b^{2}$ \\
\hline & & \multicolumn{6}{|c|}{  } \\
\hline Block & 3 & $1.43^{\mathrm{ns}}$ & $10.1 *$ & $174474.83^{\mathrm{ns}}$ & $5.3050^{\mathrm{ns}}$ & $948108.35^{\mathrm{ns}}$ & $0.0574^{\mathrm{ns}}$ \\
\hline Variety $(\mathrm{V})$ & 1 & $87.21 *$ & $210.8 * *$ & $875081.41^{\mathrm{ns}}$ & $12.611^{\mathrm{ns}}$ & $3230848.12^{\mathrm{ns}}$ & $0.1128^{\mathrm{ns}}$ \\
\hline Error 1 & 3 & 4.275 & 0.9739 & 1.037 .661 .25 & 5.9065 & 2.599 .010 .83 & 0.0327 \\
\hline Row Space (RS) & 3 & $3.645^{\mathrm{ns}}$ & $20.466 *$ & $127960.53^{\mathrm{ns}}$ & $1.7153^{\mathrm{ns}}$ & $430626.86^{\mathrm{ns}}$ & $0.0138^{\mathrm{ns}}$ \\
\hline $\mathrm{V} \times \mathrm{RS}$ & 3 & $5.151^{\mathrm{ns}}$ & $14.009^{\mathrm{ns}}$ & $218034.31^{\mathrm{ns}}$ & $1.4314^{\mathrm{ns}}$ & $537086.17^{\mathrm{ns}}$ & $0.0132^{\mathrm{ns}}$ \\
\hline Error 2 & 18 & 3.524 & 4.5746 & 361.727 .86 & 4.0801 & 1.201 .750 .44 & 0.0300 \\
\hline Time (DAS) & 4 & $25.14 * *$ & $23.38 * *$ & $4231499.3 *$ & $22.46 * *$ & $10189786.1 * *$ & $0.1624 * *$ \\
\hline $\mathrm{V} \times \mathrm{DAS}$ & 4 & $8.27 * *$ & $0.6002^{\mathrm{ns}}$ & $157809.93^{\mathrm{ns}}$ & $2.657 * *$ & $603115.58^{\mathrm{ns}}$ & $0.0274 * *$ \\
\hline $\mathrm{RS} \times \mathrm{DAS}$ & 12 & $0.7849^{\mathrm{ns}}$ & $1.0099^{\mathrm{ns}}$ & $175137.79^{\mathrm{ns}}$ & $0.7894^{\mathrm{ns}}$ & $421518.61^{\mathrm{ns}}$ & 0.0040 \\
\hline $\mathrm{V} \times \mathrm{RS} \times \mathrm{DAS}$ & 12 & $1.3467^{\mathrm{ns}}$ & $0.6259^{\mathrm{ns}}$ & $186006.05^{\mathrm{ns}}$ & $1.2366^{\mathrm{ns}}$ & $452826.51^{\mathrm{ns}}$ & $0.0117^{\mathrm{ns}}$ \\
\hline Error 3 & 96 & 0.9463 & 0.7666 & 133.887 .43 & 0.6872 & 298.547 .77 & 0.0064 \\
\hline Total & 159 & - & - & - & - & - & - \\
\hline $\mathrm{CV}_{1}$ & - & 13.38 & 6.57 & 41.00 & 32.61 & 45.67 & 12.12 \\
\hline $\mathrm{CV}_{2}$ & - & 12.15 & 14.25 & 24.21 & 27.10 & 32.05 & 11.60 \\
\hline $\mathrm{CV}_{3}$ & - & 6.30 & 5.83 & 14.73 & 11.12 & 15.48 & 5.38 \\
\hline
\end{tabular}

Note. ${ }^{1}$ : first cycle; ${ }^{2}$ : second cycle; FV: variation factors; DF: degree of freedom; QM: mean square; $\mathrm{t}$ : normalized by the boxcox system; CV: coefficient of variation; v: variety; RS: spacing between rows; PS: spacing between plants. ${ }^{\mathrm{ns}},{ }^{*},{ }^{* *}$ not significant, significant at $5 \%$, and $1 \%$ probability of error by the $\mathrm{F}$ test of ANOVA, respectively.

Figure 2A shows that the mean stalk diameter for the SF-15 variety in the first cycle was greater at 45 DAS. The observed reduction in stalk diameter over the evaluated time for the SF-15 variety was only $0.69 \mathrm{~mm}$, while the BRS 506 reduced $2.72 \mathrm{~mm}$. In the second crop cycle, the mean stalk diameter of the SF-15 variety was greater, presenting a mean of $16.15 \mathrm{~mm}$, and the BRS 506 had a mean of $13.86 \mathrm{~mm}$ (Figure 2B). The spacing between the rows that produced the largest average stalk diameter was $70 \mathrm{~cm}$, with a mean of $15.59 \mathrm{~mm}$ in the second cycle (Figure 2C). 

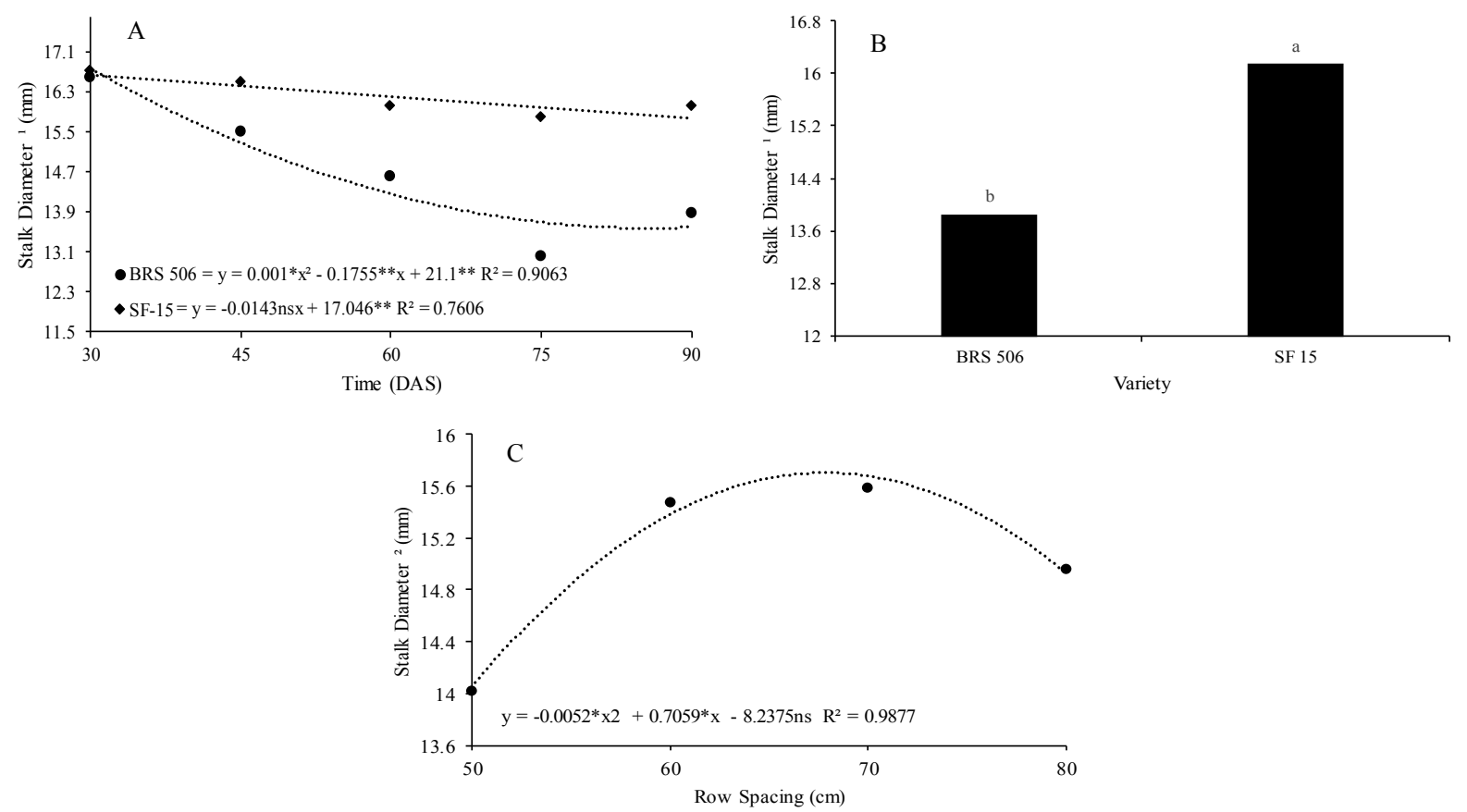

Figure 2. The stalk diameter of two sweet sorghum varieties produced in the semiarid region of Brazil in 2015 and 2016 due to different spacing between rows

Note. ${ }^{1}$ : first cycle; ${ }^{2}$ : second cycle; ${ }^{*}, * *$ : respectively, significance by the $\mathrm{F}$ test when significant at the $5 \%$ level and significant at the $1 \%$ level. ns: not significant.

The relative index values of chlorophyll are represented in Figure 3. Chlorophyll a, in the first cycle, had a greater mean at 30 DAS (36.37), with a decrease in this variable to 4.28 at 60 DAS, and an increase (35.19) to at 90 DAS (Figure 3A). Similar behavior was observed in chlorophyll b (Figure 3B) for the SF-15 variety, in the second cycle, which presented the greatest value at 30 DAS (8.12) and least at 75 DAS (5.91). For BRS 506, there was no mathematical adjustment, with an average chlorophyll $b$ of 7.73 .

Total chlorophyll (Figure 3C), in the second cycle, presented the greatest mean at 30 DAS (44.63) and least at 75 DAS (38.72). While the chlorophyll a/b ratio for the SF-15 variety reached the greatest mean at 75 DAS (1.65) and the least at 90 DAS (1.44). Again, the BRS 506 variety showed no mathematical adjustment (Figure 3D). 

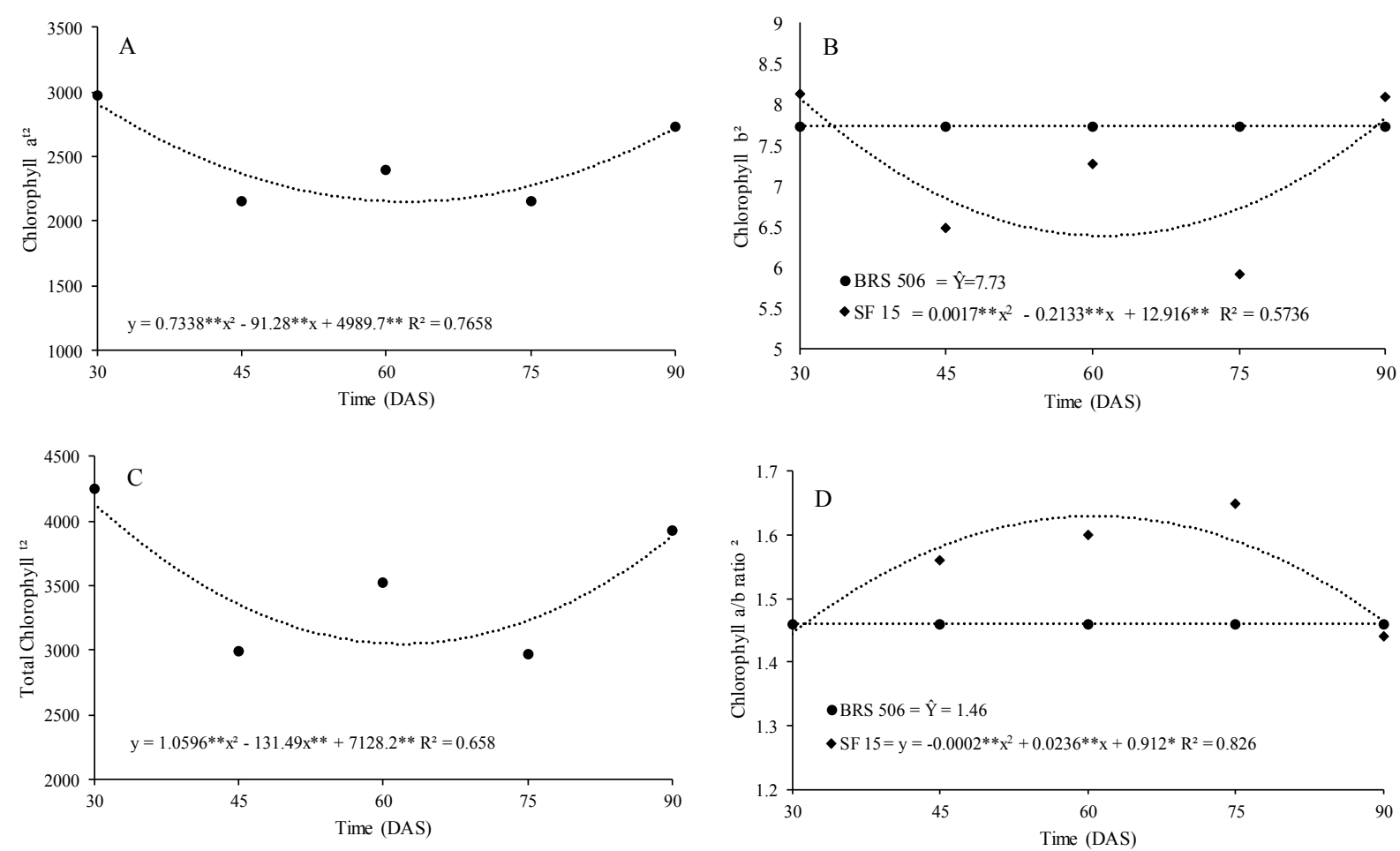

Figure 3. Relative chlorophyll index of two sweet sorghum varieties produced in the semiarid region of Brazil in 2015 due to different spacing between the rows

Note. ${ }^{2}$ : second cycle, $*{ }^{* *}$ : respectively, significance by the $\mathrm{F}$ test when significant at the $5 \%$ level and significant at the $1 \%$ level. ns: not significant. t: Data transformation by the Boxcox system $(\lambda=2.5$ (Chlorophyll $\left.\mathrm{a}^{2}\right)$ and $\lambda=2.44949($ Total chlorophyl12).

\section{Discussion}

Morphogenic characteristics are essential criterion to select appropriated genotypes for each region since adaptability and stability responses are affected by both meteorological variables and yield. The morphogenesis is conceptualized as the dynamics of generation and expansion of the plant form in a space, with this dynamic related to the constant environmental oscillations. Therefore, it must be carefully analyzed to understand the ways in which plants respond to environmental variations, as it includes the rate of appearance of new organisms, as well as their rates of expansion, senescence, and decomposition. These variables help to determine crop yield (Costa et al., 2013, Oliveira et al., 2017b).

The biomass production for sweet sorghum is directly related to plant height and stalk diameter. The sugars, mainly sucrose, which are converted to ethanol, are stored in the stalk. These characteristics are influenced by the environmental conditions and crop management (May et al., 2012).

Water scarcity is a severe environmental constraint that directly affects plant productivity. Thus, the drought-induced loss in crop yield probably exceeds losses due to other natural stresses because both severity and duration of this stress are critical (Farooq et al., 2009; Oliveira et al., 2012; Taiz et al., 2015). To escape or adapt to these situations, the plants use a variety of mechanisms to withstand/tolerate water stress. The main mechanisms include reducing water loss through opening and closing of stomata, increasing water absorption with deep and branching root systems, and decreasing plant size with smaller leaves to reduce loss through perspiration (Oliveira et al., 2017a).

The plants cultivated in the second cycle were negatively affected by the low precipitation $(284.8 \mathrm{~mm})$. Regardless of the variety and the spacing between rows, the experiment conducted in the first year of cultivation obtained greater plant height averages (Table 1), due to the better distribution and volume of water over the period of crop development, with $129.1 \%$ more precipitation than in 2016 (Figure 1).

Silva et al. (2017a), who studied the sweet sorghum (BRS 511) in the semiarid conditions of Ceará, observed a negative influence on the height of different plant populations, i.e. the greatest plant population per hectare was 
associated with the shortest height. However, greater height does not always indicate the greater dry matter production, this variable must be correlated to the diameter of the stalk. In this experiment, the SF-15 variety showed the greatest shoot mean diameter in the second year of cultivation (Figure 2B). However, its stalk characteristics, which was quite spongy, are undesirable for ethanol production, and gave the variety low values of fresh stalk mass and broth yield.

The BRS 506 variety presented the highest mean leaf number and leaf angle +3 in the two years of cultivation (Table 1). Werner et al. (2001) emphasize the importance of the position of the leaf. Leaves that are more horizontal to the soil can capture light more efficiently; however, excess light is not converted into photoproducts, which results in a lower rate of carbon gain. In contrast, leaves more perpendicular to the soil reduce the interception of the excessive radiation resulting in a reinforced the carbon gain, with a direct influence on crop productivity.

Photosynthetic pigments are good indicators of the level stress in the plants (Gomes et al., 2014). Therefore, their content is frequently monitored during the stress period, by measuring leaf color and estimating chlorophyll concentration (Pestana et al., 2001). The content of foliar chlorophyll is related to stress factors such as water and mineral deficiency, primarily nitrogen.

Leonardo et al. (2013) found a correlation between nitrogen and chlorophyll content. $\mathrm{N}$ is one element that forms the chlorophyll molecule; thus, some authors evaluate the chlorophyll content to determine nutritional status of plants, in terms of nitrogen. This finding agrees with the behavior observed in the present experiment. In the first cycle, the highest means for chlorophyll levels were observed at 75 DAS (Table 2), while in the second crop cycle, a year with low precipitation (Figure 1), the highest means were observed at 30 DAS (Figures 3A, 3B, and 3C).

The importance of sweet sorghum as an energy crop is due to some advantages such as drought tolerance, its great potential to produce biomass even under less favorable growing conditions, and the easy cultivation (Mekdad \& Rady, 2016; Silva et al., 2018). This experiment helps prove that sweet sorghum could be an important crop to cultivate in more arid regions and can operate in sugar cane renewal areas as a biofuel feedstock.

\section{Conclusions}

The highest mean stalk stalker was observed in the SF15 variety, but because it is too spongy it does not make it suitable for ethanol production. Although the BRS 506 variety showed lower height and stem height values than SF15 variety, the first one would be the most suitable aiming ethanol production due to its better growth and development. Thus, BRS 506 variety is recommended for cultivation in semiarid northeastern Brazil, which presents reasonable agronomic traits when cultivated with $70 \mathrm{~cm}$ spacing between the rows.

\section{References}

Alvares, C. A., García, F. Z., Cavazos, G. A.,Vázquez, M. D. C. R., \& Sáenz, E. O. (2014). Köppen’s climate classification map for Brazil. Meteorologische Zeitschrift, 22, 711-728. https://doi.org/10.1127/0941-2948/ 2013/0507

Bellaloui, N., Bruns, H. A., Abbas, H. K., Mengistu, A., Fisher, D. K., \& Reddy, K. N. (2015). Effects of Row-Type, Row-Spacing, Seeding Rate, Soil-Type, and Cultivar Differences on Soybean Seed Nutrition under US Mississippi Delta Conditions. PLoS ONE, 10, 1-23. https://doi.org/10.1371/journal.pone.0129913

Costa, A. F., Vale, L. S., Oliveira, A. B., Brito Neto, J. F., Ribeiro, W. S., \& Cardoso, G. D. (2017). Evaluation of yield performance in cowpea genotypes (Vigna unguiculata (L.) Walp.). Australian Journal of Crop Science, 11, 308-312. https://doi.org/10.21475/ajcs.17.11.03.pne433

Costa, N. L., Moraes, A., Carvalho, P. C. F., Monteiro, A. L. G., \& Oliveira, R. A. (2013). Características morfogênicas e estruturais de Trachypogon plumosus de acordo com a fertilidade do solo e o nível de desfolha. Pesquisa Agropecuaria Brasileira, 48, 320-328. https://doi.org/10.1590/S0100-204X20130003 00011

Embrapa (Empresa Brasileira de Pesquisa Agropecuária). (2013). Sistalka brasileiro de classificação de solos (3rd ed., p. 353).

ESTATCAMP. (2014). Software Action. Retrieved from http://www.estatcamp/empresa/software-action

Farooq, M., Wahid, A., Kobayashi, N., Fujita, D., \& Basra, S. M. A. (2009). Plant drought stress: Effects, mechanisms and management. Agronomy for Sustainable Development, 9, 185-212. https://doi.org/10.1051/ agro:2008021. 
Ferreira, D. F. (2011). Sisvar: A computer statistical analysis system. Ciência e Agrotecnologia, 6, 1039-1042. https://doi.org/10.1590/S1413-70542011000600001

Fischer-Filho, J. A., Gomes, G. G. C., Bolonhezi, A. C., Oliveira, J. A. V., \& Santos, B. T. R. R. (2014). Sacarino characteristics of growth of hybrid sorghum. Ciência \& Tecnologia, 6, 11-15.

Gomes, S. M. S., Lima, V. L., Souza, A. P., Nascimento, J. J. V. R., \& Nascimento, E. S. (2014). Cloroplast pigments as indicators of lead stress. Engenharia Agrícola, 34, 877-884. https://doi.org/10.1590/S0100-691 62014000500007

Leonardo, F. D. A. P., Pereira, W. E., Silva, S. M., \& Costa, J. P. (2013). Teor de clorofila e índice spad no abacaxizeiro cv. vitória em função da adubação nitrogenada. Revista Brasileira de Fruticultura, 35, 377-383. https://doi.org/10.1590/S0100-29452013000200006

Martins, J. R., Alvarenga, A. A., Castro, E. M., Silva, A. P. O., \& Alves, E. (2010). Teores de pigmentos fotossintéticos e estrutura de cloroplastos de Alfavaca-cravo cultivadas sob malhas coloridas. Ciência Rural, 40, 64-69. https://doi.org/10.1590/S0103-84782010000100011

May, A., Durães, F. O. M., Pereira Filho, I. A., Schaffert, R. E., \& Parrella, L. A. C. (2012). Sistema Embrapa de produção agroindustrial de sorgo sacarino para bioetanol, Sistema BRS 1G-Tecnologia qualidade Embrapa (p. 120). Sete Lagoas: Embrapa Milho e Sorgo.

Mekdad, A. A. A., \& Rady, M. M. (2016). Productivity Response to Plant Density in Five Sorghum Bicolor Varieties in Dry Environments. Annals of Agricultural \& Crop Scienses, 1, 1-7.

Moura, M. S. B., Galvincio, J. D., Brito, L. T. L., Souza, L. S. B., Sá, I. I. S., \& Silva, T. G. F. (2007). Clima e água de chuva no Semi-Árido. In L. T. de L. Brito, M. S. B. de Moura, \& G. F. B. Gama (Eds.), Potencialidades da água de chuva no Semi-Árido brasileiro (pp. 37-59).

Nunes, R. L. C., Oliveira, A. B., \& Dutra, A. S. (2014). Agronomic performance of onion hybrids in Baraúna, in the semi-arid region of Brazil. Revista Ciência Agronômica, 45, 606-611. https://oi.org/10.1590/ S1806-66902014000300023

Oliveira, A. B., Alencar, N. L. M., \& Gomes-Filho, E. (2012). Physiological and Biochemical Responses of Semiarid Plants Subjected to Water Stress. In Md. M. R. Ismail, \& Hiroshi Hasegawa (Eds.), Water Stress (1st ed., Vol. 1, pp. 43-58). Rijeka: InTech. https://doi.org/10.5772/29444

Oliveira, A. B., Alencar, N. L. M., Prisco, J. T., \& Gomes-Filho, E. (2011). Accumulation of organic and inorganic solutes in $\mathrm{NaCl}$-stressed sorghum seedlings from aged and primed seeds. Scientia Agricola, 68, 632-637. https://doi.org/10.1590/S0103-90162011000600004

Oliveira, A. B., Brito Neto, J. F., Cardoso, G. D., \& Vale, L. S. (2017b). Growth and yield of castor bean (Ricinus communis L.) cv. BRS Energia under different spacing. Tropical and Subtropical Agroecosystems, 20, 289-295.

Oliveira, H. P., Ribeiro, T. B., Machado, A. S., Silva, L. O., \& Oliveira Júnior, A. R. (2017a). Respostas fisiológicas de forrageiras ao déficit hídrico e baixas temperaturas. Nutritime Revista Eletrônica, 14, 7008-7014.

Pestana, M., David, M. M., Varennes, A., Abadia, J., \& Faria, E. A. (2001). Responses of "Newhall” orange trees to iron deficiency in hydroponics: effects on leaf chlorophyll, photosynthetic efficiency, and root ferric chelate reductase activity. Journal of Plant Nutrition, 24, 1609-1620. https://doi.org/10.1081/PLN-100 106024

Santos, R. F., Placido, H. F., Garcia, E. B., Cantú, C., Albrecht, A. J. P., Albrecht, L. P., \& Frigo, K. D. A. (2015). Sorgo sacarino na produção de agroenergia. Revista Brasileira de Energias Renováveis, 4, 1-12. https://doi.org/10.5380/rber.v3i3.39690

Silva, F. A. S., \& Azevedo, C. A. V. (2009). Principal Components Analysis in the Software Assistat-Statistical Attendance. Worluters in Agriculture, 7. Reno-NV-USA: American Society of Agricultural and Biological Engineers.

Silva, J. M. F., Dutra, A. S., Camara, F. T., Pinto, A. A., \& Silva, F. E. (2017a). Row spacing, plant density, sowing and harvest times for sweet sorghum. Pesquisa Agropecuaria Tropical, 47, 408-415. https://doi.org/ $10.1590 / 1983-40632017 \mathrm{v} 4748585$

Silva, T. M., Lopes, M. F. Q., Oliveira, A. B., Nogueira, A. L. S. P., Viana, I. E. T., \& Lessa, B. F. T. (2017b). Physiological quality of sweet sorghum [Sorghum bicolor (L.) Moench.] seeds in response to planting 
density in semi-arid region. Australian Journal of Crop Science, 11, 694-700. https://doi.org/10.21475/ ajcs.17.11.06.p420

Silva, T. M., Oliveira, A. B., Moura, J. G., Lessa, B. F. T., \& Oliveira, L. S. B. (2018). Potential of sweet sorghum juice as a source of ethanol for semi-arid regions: cultivars and spacing arrangement effects. Sugar Tech, 20, 1-8. https://doi.org/10.1007/s12355-018-0637-8

Souza, W. W. O., Oliveira, A. B., Dutra, A. S., Nunes, R. L. C., \& Cavalcante, R. A. (2016). Agronomic evaluation of cowpea as a function of weed control with herbicides and different combinations. Revista Ciência Agronômica, 47, 675-682. https://doi.org/10.5935/1806-6690.20160081

Taiz, L., Zeiger, E., Møller, I. M., \& Murphy, A. (2015). Plant Physiology and Development (6th ed.). Sinauer Associates, Inc.

Werner, C., Ryelb, R. J., Correiac, O., \& Beyschlaga, W. (2001). Structural and functional variability within the canopyand its relevance for carbon gain and stress avoidance. Acta Oecologica, 22, 129-138. https://doi.org/10.1016/S1146-609X(01)01106-7

\section{Appendix A}

Table A1. Physic and chemical conditions of the soil at depths of 0-20 and 20-40 $\mathrm{cm}$ in the experimental area of Curu Valley Farm, in Pentecoste, Ceará, Brazil, in 2015

\begin{tabular}{|c|c|c|c|c|c|c|c|c|}
\hline Depth $(\mathrm{cm})$ & $\mathrm{Ca}^{2+}$ & $\mathrm{Mg}^{2+}$ & $\mathrm{Na}^{+}$ & $\mathrm{K}^{+}$ & $\mathrm{H}^{+}+\mathrm{Al}^{3+}$ & $\mathrm{Al}^{3+}$ & $\mathrm{S}$ & $\mathrm{T}$ \\
\hline & --- & 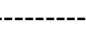 & - & - & cmolc kg & 1---- & & \\
\hline $0-20$ & 5.80 & 1.20 & 0.33 & 0.49 & 1.49 & 0.15 & 7.8 & 9.3 \\
\hline $20-40$ & 5.40 & 1.60 & 0.37 & 0.35 & 1.16 & 0.10 & 7.7 & 8.9 \\
\hline \multirow[t]{2}{*}{ Depth $(\mathrm{cm})$} & $\mathrm{V}$ & $\mathrm{M}$ & $\mathrm{C}$ & $\mathrm{N}$ & $\mathrm{MO}$ & $\mathrm{P}$ absorbed & $\mathrm{C} / \mathrm{N}$ & PST \\
\hline & \multicolumn{2}{|c|}{------ \% ----י- } & (------י & - & $\mathrm{g} \mathrm{kg}^{-1}$ & - & & \\
\hline $0-20$ & 84 & 2 & 6.66 & 0.73 & 11.48 & 0.086 & 9 & 4 \\
\hline $20-40$ & 87 & 1 & 3.72 & 0.34 & 6.41 & 0.053 & 11 & 4 \\
\hline \multirow[t]{2}{*}{ Depth $(\mathrm{cm})$} & D.G. & $\mathrm{pH}$ & $\mathrm{CE}$ & Sand G & Sand F & Silt & Avg. & Nat. Avg. \\
\hline & $\mathrm{g} \mathrm{cm}^{-3}$ & $\mathrm{H}_{2} \mathrm{O}$ & $\mathrm{dS} \mathrm{m}^{-1}$ &  & - & $\mathrm{g} \mathrm{kg}^{-1}$ &  & \\
\hline $0-20$ & 1.46 & 6.7 & 0.85 & 68 & 593 & 249 & 90 & 61 \\
\hline $20-40$ & 1.55 & 7.0 & 0.66 & 50 & 571 & 271 & 108 & 92 \\
\hline
\end{tabular}

Source: Soil/Water Laboratory; Department of Soil Science, Federal University of Ceara (UFC); Foundation of Meteorology and Water Resources of Ceara State, FUNCEME, Brazil.

Table A2. Physic and chemical conditions of the soil at depths of 0-20 and 20-40 cm in the experimental area of Curu Valley Farm, in Pentecoste, Ceará, Brazil, 2016

\begin{tabular}{|c|c|c|c|c|c|c|c|c|}
\hline Depth $(\mathrm{cm})$ & $\mathrm{Ca}^{2+}$ & $\mathrm{Mg}^{2+}$ & $\mathrm{Na}^{+}$ & $\mathrm{K}^{+}$ & $\mathrm{H}^{+}+\mathrm{Al}^{3+}$ & $\mathrm{Al}^{3+}$ & $\mathrm{S}$ & $\mathrm{T}$ \\
\hline & \multicolumn{8}{|c|}{ 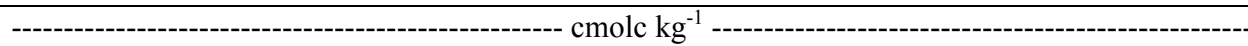 } \\
\hline $0-20$ & 5.40 & 2.10 & 0.22 & 0.96 & 0.83 & 0.05 & 8.7 & 9.5 \\
\hline $20-40$ & 4.70 & 3.30 & 0.63 & 0.74 & 0.66 & 0.05 & 9.4 & 10.0 \\
\hline \multirow[t]{2}{*}{ Depth $(\mathrm{cm})$} & $\mathrm{V}$ & $\mathrm{M}$ & $\mathrm{C}$ & $\mathrm{N}$ & $\mathrm{MO}$ & P absorbed & $\mathrm{C} / \mathrm{N}$ & PST \\
\hline & \multicolumn{6}{|c|}{----------- \% ----------- } & & \\
\hline $0-20$ & 91 & 1 & 9.48 & 0.98 & 16.34 & 0.084 & 10 & 4 \\
\hline $20-40$ & 93 & 1 & 5.16 & 0.53 & 8.90 & 0.061 & 10 & 4 \\
\hline \multirow[t]{2}{*}{ Depth $(\mathrm{cm})$} & D.G. & $\mathrm{pH}$ & $\mathrm{CE}$ & Sand $\mathrm{G}$ & Sand F & Silt & Avg. & Nat. Avg. \\
\hline & $\mathrm{g} \mathrm{cm}^{-3}$ & $\mathrm{H}_{2} \mathrm{O}$ & $\mathrm{dS} \mathrm{m}^{-1}$ & \multicolumn{5}{|c|}{ 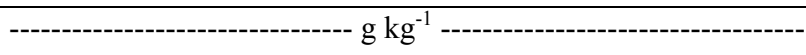 } \\
\hline $0-20$ & 1.37 & 6.6 & 0.58 & 60 & 556 & 261 & 123 & 80 \\
\hline $20-40$ & 1.6 & 6.8 & 0.70 & 69 & 578 & 258 & 95 & 77 \\
\hline
\end{tabular}

Source: Soil/Water Laboratory; Department of Soil Science, Federal University of Ceara (UFC); Foundation of Meteorology and Water Resources of Ceara State, FUNCEME, Brazil. 


\section{Copyrights}

Copyright for this article is retained by the author(s), with first publication rights granted to the journal.

This is an open-access article distributed under the terms and conditions of the Creative Commons Attribution license (http://creativecommons.org/licenses/by/4.0/). 